\title{
The Adsorption of Cetyltrimethylammonium Bromide by Bacteria, its Action in Releasing Cellular Constituents and its Bactericidal Effects
}

\author{
By M. R. J. SALTON \\ Department of Colloid Science, University of Cambridge
}

SUMMARY: The form of the uptake curve of cetyltrimethylammonium bromide (CTAB) by Staphylococcus aureus and Escherichia coli is that of an adsorption isotherm. Tested on six different bacteria, the maximum amounts of CTAB adsorbed showed variations from one organism to another.

When cells of Staphylococcus aureus, Streptococcus faecalis, Escherichia coli or Salmonella pullorum are suspended in water, the ultra-violet spectrum of the supernatant liquid has a maximum absorption at a wave-length of $260 \mathrm{~m} \mu$. The height of this maximum is greatly increased when the cells are suspended in CTAB solutions instead of water. Free purines and pyrimidines contribute to this maximum.

There is a parallel relationship between the leakage of $260 \mathrm{~m} \mu$.-absorbing material, glutamic acid and inorganic phosphorus from two CTAB-treated Gram-positive bacteria, when their release is followed during the initial rapid phase of leakage. There is a similar relationship for Esch. coli, although no glutamic acid is released. Release of cell constituents from CTAB-treated Staph. aureus continues slowly for some time after the initial process and is accompanied by a decrease in dry weight of the cells and a gradual change from positive to negative in their Gram-staining reaction. The rate of release of cellular constituents was increased by raising the temperature or by treatment with high concentrations of CTAB.

Treatment of suspensions with sufficient CTAB to sterilize them released amounts of cell constituents comparable to those released by placing the cells in boiling water. When smaller amounts of CTAB were used, a quantitative relationship was found between the amount of CTAB present, the proportion of cells killed and the amount of $260 \mathrm{~m} \mu$.-absorbing material released.

Many surface-active agents are bactericidal and various explanations have been proposed to account for this action. Baker, Harrison \& Miller (1941) suggested that detergents disorganize the cell membrane and denature certain proteins essential to metabolism and growth. Kuhn \& Bielig (1940) observed that germicidal concentrations of some detergents correspond to concentrations effecting denaturation of proteins. Hotchkiss (1944, 1946) found that treatment of bacterial cells with certain surface-active compounds in bactericidal concentrations released nitrogenous and phosphorus-containing substances. Gale \& Taylor (1947) demonstrated that the nitrogenous substances released included the free amino-acids concentrated within the cells of Strep. faecalis; Mitchell \& Crowe (1947) showed that this action was accompanied by an alteration in the surface structure of the cells, as shown by the electron microscope. By growing Staph. aureus and Pseudomonas fluorescens on media containing radioactive phosphorus $\left(\mathrm{P}^{32}\right)$, Salton (1950) showed that there was an increased leakage of $\mathrm{P}^{32}$ into the suspending fluid when CTAB was present. The release of purines and pyrimidines from Staph. aureus treated with CTAB was reported by Salton \& Alexander (1950). 
The inhibition of bacterial metabolism by surface-active compounds was interpreted by Hotchkiss (1946) as evidence against the idea that an essential, detergent-sensitive enzyme exists. On the other hand, Knox, Auerbach, Zarudnaya \& Spirtes (1949) showed that cell-free preparations of certain enzymes from Esch. coli are inhibited at detergent/protein ratios which are bactericidal for the intact cells. They concluded that the specific inhibition of detergent-sensitive enzymes, such as the lactic acid oxidase, could account for metabolic inhibition, cell death and increased permeability observed in bacteria treated with bactericidal amounts of the cationic detergents.

The present communication deals with the adsorption of CTAB by bacteria, the disorganization of their cell membranes, and the subsequent release of certain cellular constituents. Cytological studies of the cellular disorganization were carried out in parallel and are reported by Salton, Horne \& Cosslett (1951).

\section{METHODS}

Organisms. Staph.aureus and Proteus vulgaris investigated by Salton (1950); Strep. faecalis ST (N.C.T.C. no. 6782); a strain of Bacillus pumilus and Esch. coli $\mathbf{H}$ (kindly given by $\mathrm{Dr}$ E. F. Gale); Salm. pullorum (kindly given by Dr R. Coombs) were used in these investigations.

Medium, conditions of culture and harvesting. The organisms were grown in a medium consisting of c. $3 \%$ tryptic digest of casein, $0.1 \%$ Marmite and $1 \%$ glucose, at an initial pH $7 \cdot 4-7 \cdot 6$. Roux bottles of medium inoculated with c. $10 \mathrm{ml}$. of overnight culture were incubated for $16 \mathrm{hr}$. at $37^{\circ}$. The cells were harvested from the liquid medium by centrifugation, washed three times with distilled water on the centrifuge and finally suspended in distilled water to give a suspension containing $c .15 \mathrm{mg}$. dry-weight bacteria/ml.

Dry-weight determinations. The dry weights of the washed bacterial suspensions were determined directly, by drying $1 \mathrm{ml}$. samples of the dense suspensions to constant weight in an air-oven at $105^{\circ}$.

Adsorption of $C T A B$. The amount of CTAB adsorbed was determined by adding bacterial suspensions to solutions containing known amounts of CTAB, allowing them to stand at $20^{\circ}$ for $15 \mathrm{~min}$., removing the cells by centrifugation and estimating the residual CTAB in the supernatant liquid by the method of Salton \& Alexander (1949).

Release of cellular constituents and their estimation in the supernatant fluid. The release of cellular constituents was examined after three types of treatment: (1) cells suspended in distilled water; (2) cells suspended in CTAB solutions; (3) cells pipetted into distilled water at $c .100^{\circ}$ and then held at that temperature for $10 \mathrm{~min}$. (referred to subsequently as 'boiled' cells). In each case the final suspension density was $c .1 .5 \mathrm{mg}$. dry-weight cells $/ \mathrm{ml}$. Samples from suspensions were centrifuged for $5 \mathrm{~min}$. to remove most of the cells, and the supernatant finally cleared by further centrifugation. The cell-free supernatants were then analysed for released constituents. For the estimation of some constituents (glutamic acid, purines, pyrimidines) it was necessary to concentrate the supernatant liquids by evaporation to dryness in vacuo and to re-dissolve the residues in small volumes of distilled water. 
The following methods were used in estimating quantities of released cellular constituents :

(a) Ultra-violet spectra were studied by use of the Beckman photoelectric spectrophotometer.

(b) Inorganic phosphorus content was estimated by the method of Fiske \& Subbarow (1925). Total phosphorus was determined by the procedure of Umbreit, Burris \& Stauffer (1945).

(c) Pentose was determined by the method of Mejbaum (1939). D-Ribose was used as the standard for a calibration curve.

(d) Glutamic acid was estimated by the amino-acid decarboxylase method of Gale (1945).

(e) Purines, pyrimidines and derivatives. Paper chromatography was used for the identification and estimation of the purines, pyrimidines and derivatives in the supernatants from bacterial suspensions. These were concentrated and volumes of not more than $\mathbf{0 . 1} \mathrm{ml}$. then placed on Whatman filter-paper No. $\mathbf{1}$, according to the method of Hotchkiss (1948). Of the solvent systems tried, $n$-butanol saturated with water and $5 \%(\mathrm{v} / \mathrm{v})$ formic acid gave the best separations. Chromatograms were run with guanine, adenine, uracil and cytosine as markers. The locations of substances on the chromatograms were found by the method of Markham \& Smith(1949). For quantitative estimations, the areas of filter-paper corresponding with spots on the developed chromatogram were cut out, extracted with $4 \mathrm{ml}$. distilled water and estimated at neutral $\mathrm{pH}$ in the Beckman spectrophotometer. Filter-paper blanks were obtained by cutting out adjacent areas of equal size as recommended by Hotchkiss (1948). A check on recovery was obtained by running known amounts of purines and pyrimidines and extracting from the chromatograms.

Plate-count estimation of surviving cells. Samples of bacterial suspensions $(1.0 \mathrm{ml}$.) were withdrawn at intervals and transferred to $99 \mathrm{ml}$. sterile tap water. Suitable dilutions were then plated out, in duplicate, in the growth medium containing $2 \%$ agar and the colonies counted after $48 \mathrm{hr}$. incubation at $37^{\circ}$.

\section{RESULTS}

\section{Adsorption of $C T A B$ by bacteria}

The amount of CTAB taken up by Staph. aureus and Esch. coli is expressed in Fig. 1 as a function of the CTAB concentration in the supernatant. The results suggest typical adsorption isotherms. Similar curves were obtained with Strep. faecalis, B. pumilus, Salm. pullorum and Pr. vulgaris. Marked agglutination of the suspensions was observed in the region of maximum CTAB uptake. The level of maximum CTAB adsorption varies somewhat from one organism to another. Table 1 shows maximum amounts of CTAB adsorbed and the weight ratios of bacteria:adsorbed CTAB, for a number of bacterial species.

Release of ultra-violet absorbing material and identification of some of its components

An examination of the ultra-violet spectra of supernatants from suspensions of Staph. aureus in distilled water and solutions containing $90 \mu \mathrm{g}$. CTAB $/ \mathrm{ml}$, 
Table 1. Comparison of maximum amounts of cetyltrimethylammonium bromide adsorbed by various bacteria

\begin{tabular}{lcc}
\multicolumn{1}{c}{$\begin{array}{c}\text { CTAB adsorbed } \\
\text { Organism }\end{array}$} & $\begin{array}{c}\text { Weight ratio } \\
\text { bacteria) }\end{array}$ & Bacteria:CTAB \\
Staph. aureus & 320 & $3: 1$ \\
Strep. faecalis & 430 & $2 \cdot 3: 1$ \\
B. pumilus & 600 & $1 \cdot 7: 1$ \\
Esch. coli & 420 & $2 \cdot 4: 1$ \\
Salm. pullorum & 340 & $3: 1$ \\
Pr. vulgaris & 355 & $2 \cdot 8: 1$
\end{tabular}

revealed a maximum absorption at a wave-length of $260 \mathrm{~m} \mu$. A marked increase in the $260 \mathrm{~m} \mu$. absorption of the supernatant from CTAB-treated cells was observed. Fig. 2 shows the ultra-violet spectra of these supernatant fluids. Spectra of supernatants from untreated and CTAB-treated Strep. faecalis, Esch. coli and Salm. pullorum also showed maxima at $260 \mathrm{~m} \mu$., with marked increases in the $260 \mathrm{~m} \mu$. absorption when cells had been treated with $90 \mu \mathrm{g}$. CTAB $/ \mathrm{ml}$. The absorption of the supernatants at $260 \mathrm{~m} \mu$. obeyed BeerLambert's Law up to $c . \mathbf{1 \cdot 2}$ optical density units.

Paper chromatography of concentrated supernatants from untreated and CTAB-treated suspensions of Staph. aureus showed the presence of a number of components which contribute to the ultra-violet maximum at $260 \mathrm{~m} \mu$. Guanine, adenine and uracil were found in the supernatants from untreated suspensions, while guanine, adenine, uracil and adenine riboside were the main components in the supernatant from the CTAB-treated cells. The identification of the free bases guanine, adenine and uracil was confirmed by comparing the spectra of eluted supernatant spots with the spectra of recovered markers and standard solutions of the appropriate bases. The presence of adenine riboside was established by elution from the chromatogram, hydrolysis in $\mathrm{N}-\mathrm{HCl}$ for $1 \mathrm{hr}$. and running the hydrolysate on a chromatogram; only one spot, corresponding to adenine, then appeared on the chromatogram. Quantitative data on the release of adenine and uracil which appeared to be present in greater amounts than the other components are given below.

\section{Release of $260 \mathrm{~m} \mu$. -absorbing material relative to other cellular constituents}

The release of glutamic acid (known to be concentrated as the free amino-acid in the internal environment of Gram-positive bacteria; Taylor, 1947) was followed concurrently with the appearance of $260 \mathrm{~m} \mu$.-absorbing material and inorganic $P$. The parallel relationship between the release at $20^{\circ}$ of all three cellular constituents from Staph. aureus treated with $90 \mu \mathrm{g}$. CTAB $/ \mathrm{ml}$. is shown in Fig. 3. Similar leakage curves were also found with CTAB-treated Strep. faecalis and Esch. coli, although no glutamic acid was released from the latter organism. Untreated suspensions of the three bacteria showed a steady release of $260 \mathrm{~m} \mu$-absorbing material, but there appeared to be no significant leakage of inorganic $\mathbf{P}$ and glutamic acid. The data for the leakage from untreated and 


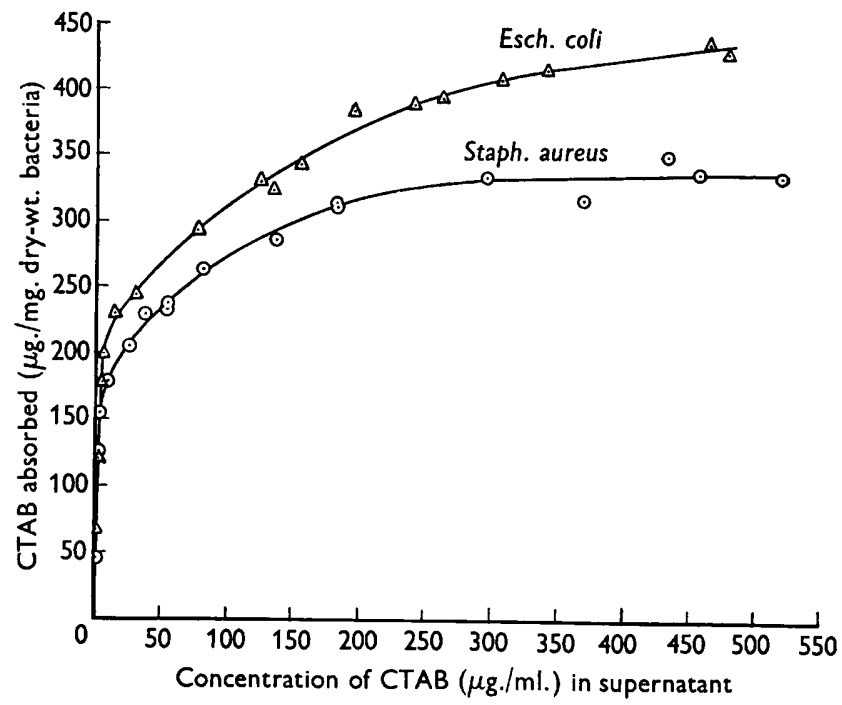

Fig. 1. Adsorption of CTAB by Staph. aureus and Esch. coli plotted as a function of the CTAB concentration in the supernatant fluid.

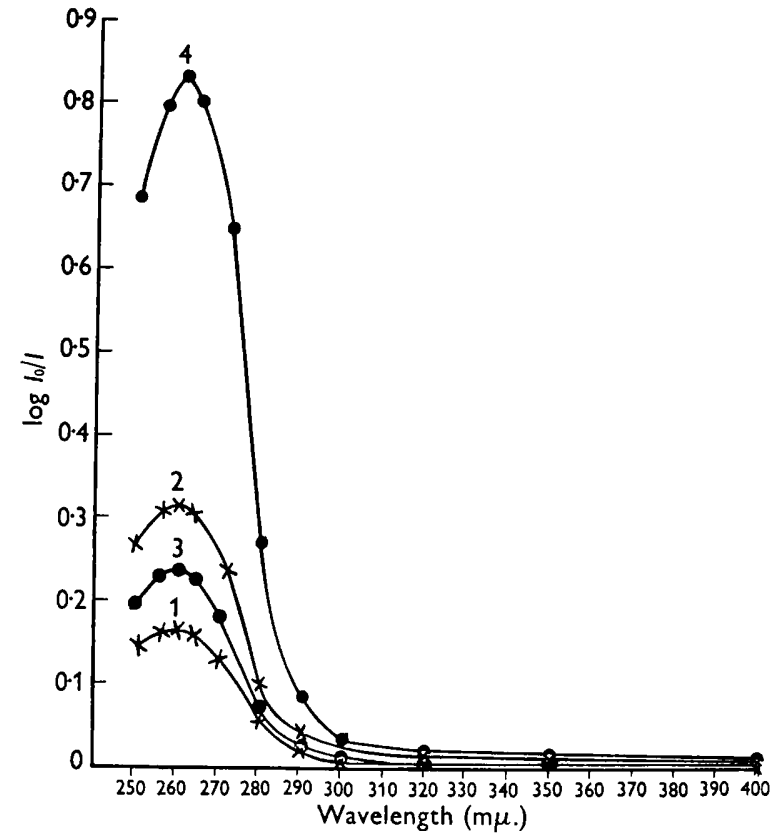

Fig. 2. Ultra-violet spectra of supernatants from Staph. aureus suspensions (1.5 mg. dry-wt. cells $/ \mathrm{ml}$.) held at $20^{\circ} . \quad \times-\times$, distilled water: curve 1 , initial sample; curve 2, $180 \mathrm{~min}$. - t treated with $90 \mu \mathrm{g}$. CTAB $/ \mathrm{ml}$. c curve 3, $5 \mathrm{~min}$. exposure; curve 4, $180 \mathrm{~min}$. exposure. 
CTAB-treated suspensions of the three organisms are shown in Table 2. Both untreated and treated cells of Staph. aureus and Strep. faecalis stained Grampositive throughout the course of the experiment.

\section{Table 2. Release of cellular constituents from untreated and CTAB-treated bacteria at $\mathbf{2 0}^{\circ}$}

A, $260 \mathrm{~m} \mu$.-absorbing material $\log \left[I_{0} / I\right]$. B, inorganic phosphorus ( $\mu \mathrm{g} . / \mathrm{mg}$. dry wt. cells). C, glutamic acid ( $\mu \mathrm{g} . / \mathrm{mg}$. dry wt. cells)

\begin{tabular}{|c|c|c|c|c|c|c|c|c|}
\hline \multirow[t]{2}{*}{ Organism } & & 0 & 5 & 10 & 30 & 60 & 120 & 180 \\
\hline & & \multicolumn{7}{|c|}{ Quantities of cellular constituents released } \\
\hline \multirow{5}{*}{$\begin{array}{l}\text { Staph. aureus* } \\
\text { Untreated } \\
\text { CTAB-treated, } \\
90 \mu \mathrm{g} . / \mathrm{ml} .\end{array}$} & & & & & & & & \\
\hline & $\mathbf{A}$ & $0 \cdot 05$ & - & 一 & 0.07 & $0 \cdot 10$ & $0 \cdot 14$ & $0 \cdot 19$ \\
\hline & $\mathbf{A}$ & - & $\mathbf{0} \cdot \mathbf{3 0}$ & $\mathbf{0} \cdot \mathbf{3 6}$ & $0 \cdot 52$ & 0.71 & $\mathbf{0} \cdot \mathbf{8 6}$ & $0 \cdot 90$ \\
\hline & $\mathbf{B}$ & - & 0.9 & $1 \cdot 3$ & $\mathbf{2 \cdot 3}$ & $\mathbf{3 \cdot 0}$ & $3 \cdot 4$ & $3 \cdot 6$ \\
\hline & $\mathbf{C}$ & 一 & $6 \cdot 1$ & $7 \cdot 7$ & $12 \cdot 6$ & $15 \cdot 6$ & - & $19 \cdot 2$ \\
\hline \multicolumn{9}{|l|}{ Strep. faecalis* } \\
\hline Untreated & $\mathbf{A}$ & 0.05 & 一 & - & 0.06 & $0 \cdot 07$ & 一 & $\mathbf{0} \cdot 10$ \\
\hline CTAB-treated, & $\mathbf{A}$ & - & .50 & - & 0.59 & 0.65 & - & 0.73 \\
\hline $45 \mu \mathrm{g} . / \mathrm{ml}$ & B & 一 & $\mathbf{3} \cdot \mathbf{1}$ & - & $\mathbf{3} \cdot \mathbf{3}$ & $3 \cdot 4$ & - & $3 \cdot 7$ \\
\hline & $\mathbf{C}$ & - & $9 \cdot 6$ & - & $11 \cdot 2$ & $11 \cdot 9$ & - & $14 \cdot 0$ \\
\hline \multicolumn{9}{|l|}{ Esch. coli $\uparrow$} \\
\hline Untreated & $\mathbf{A}$ & 0.07 & - & 一 & 0.09 & $0 \cdot 10$ & $0 \cdot 12$ & $0 \cdot 14$ \\
\hline CTAB-treated, & $\mathbf{A}$ & - & $0 \cdot 30$ & $0 \cdot 34$ & $0 \cdot 42$ & $0 \cdot 49$ & 0.57 & $0 \cdot 62$ \\
\hline $90 \mu \mathrm{g} . / \mathrm{ml}$ & B & 一 & 0.5 & 0.6 & $0 \cdot 8$ & $1 \cdot 0$ & $1 \cdot 2$ & $1 \cdot 3$ \\
\hline
\end{tabular}

\section{Effect of temperature on the release of cellular constituents from Staphylococcus aureus}

When Staph. aureus cells were treated with $90 \mu \mathrm{g}$. CTAB $/ \mathrm{ml}$. at 0,20 and $30^{\circ}$, appreciable differences in the rates of release of cellular constituents were observed. Plate-count estimations of survivors revealed $99.99 \%$ killing in $5 \mathrm{~min}$. at both 20 and $30^{\circ}$. The initial rates of release of $260 \mathrm{~m} \mu$.-absorbing material and inorganic $\mathbf{P}$ from CTAB-treated cells were determined over periods of 200,40 and $20 \mathrm{~min}$. at 1,20 and $30^{\circ}$ respectively. Control rates of release of $260 \mathrm{~m} \mu$-absorbing material from untreated cells were determined over $180 \mathrm{~min}$. at the three temperatures. The data are summarized in Table 3.

\section{Comparison of the amounts of cellular constituents released from $C T A B$-treated cells with those from 'boiled' cells}

On exposure of cells of the three organisms Staph. aureus, Strep. faecalis and Esch. coli to $90 \mu \mathrm{g}$. CTAB $/ \mathrm{ml}$. at $20^{\circ}$ for $180 \mathrm{~min}$., virtually all of the cells were killed ( $99.99 \%$ mortality). Under these conditions, the amounts of constituents released into the suspending fluid were observed to approach maxima (e.g. Fig. 3 for Staph. aureus). Analyses of supernatants from CTAB-treated bacteria revealed quantities of cellular constituents comparable to the amounts released when suspensions were pipetted into water held in a boiling water-bath. The 
Table 3. Influence of temperature on the rate of release of cellular constituents from Staph. aureus

\begin{tabular}{|c|c|c|c|}
\hline \multirow[b]{3}{*}{$\begin{array}{l}\text { Temp. } \\
\left({ }^{\circ} \mathrm{C} .\right)\end{array}$} & \multicolumn{3}{|c|}{ Rate of release of constituents } \\
\hline & \multirow[b]{2}{*}{$\begin{array}{c}\text { Control, } \\
\mathbf{2 6 0} \mathrm{m} \mu .- \\
\text { absorbing } \\
\text { material* }\end{array}$} & \multicolumn{2}{|c|}{ Treated with $90 \mu \mathrm{g}$. CTAB $/ \mathrm{ml}$} \\
\hline & & $\begin{array}{l}260 \mathrm{~m} \mu .- \\
\text { absorbing } \\
\text { material* }\end{array}$ & $\begin{array}{c}\text { Inorganic } \\
\text { phosphorus } \dagger\end{array}$ \\
\hline $\mathbf{0}$ & $0 \cdot 085$ & $0 \cdot 880$ & 0.005 \\
\hline 20 & 0.551 & $7 \cdot 615$ & 0.056 \\
\hline 30 & 0.744 & $18 \cdot 950$ & $0 \cdot 122$ \\
\hline
\end{tabular}

* Rate expressed as $10^{3} \times \log I_{0} / I / \mathrm{mg}$. dry wt. bacteria/min.

$\dagger$ Rate expressed as $\mu \mathrm{g}$. phosphorus/mg. dry wt. bacteria/min.

Table 4. A comparison of the quantities of cellular constituents released from $C T A B$-treated bacteria with those from 'boiled' cells

A, untreated suspensions held for $180 \mathrm{~min}$. at $20^{\circ}$. B, suspensions treated with $90 \mu \mathrm{g}$. CTAB $/ \mathrm{ml}$. for $180 \mathrm{~min}$. at $20^{\circ}$. C, 'boiled' cells.
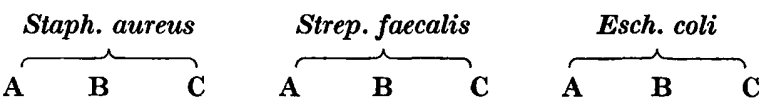

\section{Constituents estimated \\ Inorganic phosphorus \\ Total phosphorus \\ Pentose \\ Glutamic acid \\ Adenine}

(a) Unhydrolysed supernatant

(b) Hydrolysed supernatant, $\mathrm{N}-\mathrm{HCl}, \mathbf{l} \mathrm{hr}$.

Uracil

$\mu$ g. released constituent/mg. dry wt. bacteria

$\begin{array}{rrrrrrrrr}0 & 3.6 & 3.5 & 0 & 3.6 & 4.1 & 0 & 1 \cdot 1 & 1 \cdot 0 \\ 0 & 5.4 & 5.5 & 0 & 5 \cdot 1 & 5.2 & 0 & 1.9 & 3.3 \\ 0 & 4.9 & 6 \cdot 6 & 0 & 7 \cdot 3 & 7 \cdot 7 & 0 & 4 \cdot 8 & 13.0 \\ 0 & 26.6 & 27.8 & 0 & 10.7 & 11.2 & 0 & 0 & 0\end{array}$

$\begin{array}{llllll}0.4 & 1.8 & - & - & - & -\end{array}$

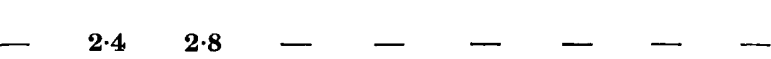

$\begin{array}{llll}0.6 & 1 \cdot 4 & 0 & 0\end{array}$

amounts of adenine and uracil contributing to the leakage of $260 \mathrm{~m} \mu$-absorbing material from untreated suspensions of Staph. aureus were estimated. The data are shown in Table 4.

\section{Effect of CTAB concentration on the release of $260 \mathrm{~m} \mu$. -absorbing material}

The amounts of $260 \mathrm{~m} \mu$.-absorbing material appearing in the suspending fluids were estimated for a range of CTAB concentrations from 22.5 to $900 \mu \mathrm{g}$./ ml. Samples were taken after 5, 30 and $180 \mathrm{~min}$. exposure at $20^{\circ}$ to the CTAB solutions. At least four estimations were made for each CTAB concentration and sampling-time. Fig. 4 shows the results obtained with Staph. aureus and illustrates those obtained also with Strep. faecalis and Esch. coli; the complete data are recorded in Table 5.

The data show that leakage of $260 \mathrm{~m} \mu$-absorbing material was a slower process for Staph. aureus and Esch. coli than for Strep. faecalis when the CTAB 
Table 5. Effect of $C T A B$ concentration on the release of $260 \mathrm{~m} \mu$. -absorbing material from various organisms

\begin{tabular}{|c|c|c|c|c|c|c|c|c|c|}
\hline \multirow[b]{2}{*}{$\begin{array}{c}\text { C'TAB } \\
\text { concen- } \\
\text { tration } \\
(\mu \mathrm{g} . / \mathrm{ml} .)\end{array}$} & \multicolumn{3}{|c|}{ Staph. aureus } & \multicolumn{3}{|c|}{ Strep. faecalis } & \multicolumn{3}{|c|}{ Esch. coli } \\
\hline & $5 \mathrm{~min}$. & $30 \mathrm{~min}$. & 180 min. & $\begin{array}{l}5 \mathrm{~min} . \\
\mu .-\mathrm{abso} \\
\log \left(I_{0} / I\right.\end{array}$ & $\begin{array}{l}30 \text { min. } \\
\text { bing ma } \\
\text { /mg. dry }\end{array}$ & $\begin{array}{l}180 \text { min. } \\
\text { rial relea } \\
\text { wt. cells) }\end{array}$ & $\begin{array}{l}5 \mathrm{~min} . \\
\text { sed }\end{array}$ & $30 \mathrm{~min}$. & $180 \mathrm{~min}$. \\
\hline $22 \cdot 5$ & 0.017 & $0 \cdot 035$ & $0 \cdot 182$ & $0 \cdot 182$ & $0 \cdot 220$ & $0 \cdot 300$ & $0 \cdot 036$ & - & - \\
\hline 45 & $0 \cdot 036$ & $0 \cdot 090$ & $0 \cdot 4,20$ & $0 \cdot 344$ & $0 \cdot 378$ & $0 \cdot 435$ & 0.069 & 0.096 & $0 \cdot 124$ \\
\hline 90 & $0 \cdot 120$ & $0 \cdot 325$ & $0 \cdot 450$ & $0 \cdot 440$ & $0 \cdot 445$ & $0 \cdot 465$ & $0 \cdot 178$ & $0 \cdot 228$ & $0 \cdot 325$ \\
\hline 135 & $0 \cdot 250$ & 0.448 & $0 \cdot 450$ & $0 \cdot 454$ & $0 \cdot 456$ & $0 \cdot 457$ & $0 \cdot 231$ & - & - \\
\hline 180 & $0 \cdot 355$ & 0.453 & 一 & $0 \cdot 460$ & $0 \cdot 456$ & 0.453 & 0.272 & $0 \cdot 321$ & $0 \cdot 323$ \\
\hline 270 & $0 \cdot 430$ & 0.450 & $0 \cdot 450$ & 0.455 & $0 \cdot 456$ & $0 \cdot 453$ & $\mathbf{0} \cdot 281$ & $0 \cdot 325$ & $0 \cdot 325$ \\
\hline 450 & 0.375 & 0.400 & $0 \cdot 424$ & $0 \cdot 403$ & $0 \cdot 410$ & $0 \cdot 414$ & $\mathbf{0} \cdot \mathbf{2 5 7}$ & $0 \cdot 325$ & $>0.500$ \\
\hline 630 & $0 \cdot 345$ & $0 \cdot 370$ & 0.447 & $0 \cdot 356$ & $0 \cdot 358$ & $0 \cdot 377$ & $0 \cdot 326$ & $0 \cdot 384$ & $>0.500$ \\
\hline 900 & $0 \cdot 438$ & $0 \cdot 480$ & 0.504 & 0.356 & 0.375 & $0 \cdot 400$ & $0 \cdot 336$ & $0 \cdot 440$ & $>0.500$ \\
\hline
\end{tabular}

concentrations were below c. $200 \mu \mathrm{g} . / \mathrm{ml}$. With $S$ trep. faecalis the release was virtually complete in $5 \mathrm{~min}$. for CTAB concentrations between 90 and $270 \mu \mathrm{g}$. ml. As the CTAB concentration was increased above $270 \mu \mathrm{g}$. $/ \mathrm{ml}$., the $260 \mathrm{~m} \mu$. absorbing material appearing in the supernatants from the three bacteria fell to a minimum and rose again. These discontinuities appeared in the region of maximum CTAB uptake by the cells. To test several possibilities which may account for the discontinuities, Staph. aureus was treated with $270 \mu \mathrm{g}$. CTAB/ml. for $30 \mathrm{~min}$. Under these conditions most of the CTAB was adsorbed, concentrations of residual CTAB were found to be less than $10 \mu \mathrm{g} . / \mathrm{ml}$. and the release of $260 \mathrm{~m} \mu$.-absorbing material had ceased (see Fig. 4). When CTAB was added to give final concentrations in the supernatant of 100-500 $\mu \mathrm{g}$. CTAB $/ \mathrm{ml}$., no change in the optical density or absorption maximum could be detected. Further, the addition of CTAB to supernatants showed no traces of turbidity or precipitate formation. The addition of more CTAB to suspensions previously treated with $270 \mu \mathrm{g}$. CTAB $/ \mathrm{ml}$. resulted in a $5 \%$ decrease in the amount of $260 \mathrm{~m} \mu$.-absorbing material found in the supernatant. Adsorption of some of the $260 \mathrm{~m} \mu$-absorbing material on the CTAB-saturated cells, would therefore partly account for the fall to a minimum shown in Fig. 4.

\section{Relationship between bactericidal effects, amount of $C T A B$ and release of $260 \mathrm{~m} \mu$.-absorbing material}

The bactericidal activity of CTAB was followed concomitantly with the release of $260 \mathrm{~m} \mu$.-absorbing material from suspensions of Staph. aureus, Strep. faecalis, Esch. coli and Salm. pullorum. Samples for estimating surviving bacteria and $260 \mathrm{~m} \mu$.-absorbing material released were taken after 5 and $30 \mathrm{~min}$. exposure to CTAB at $20^{\circ}$. Estimations of viable cells from untreated suspensions held for $30 \mathrm{~min}$. at $20^{\circ}$ showed no differences from the initial populations. The bactericidal effects of $22 \cdot 5$ and $45 \mu \mathrm{g}$. CTAB $/ \mathrm{ml}$. on known weights of the four organisms, together with the amounts of $260 \mathrm{~m} \mu$.-absorbing material released, are shown in Table 6. 


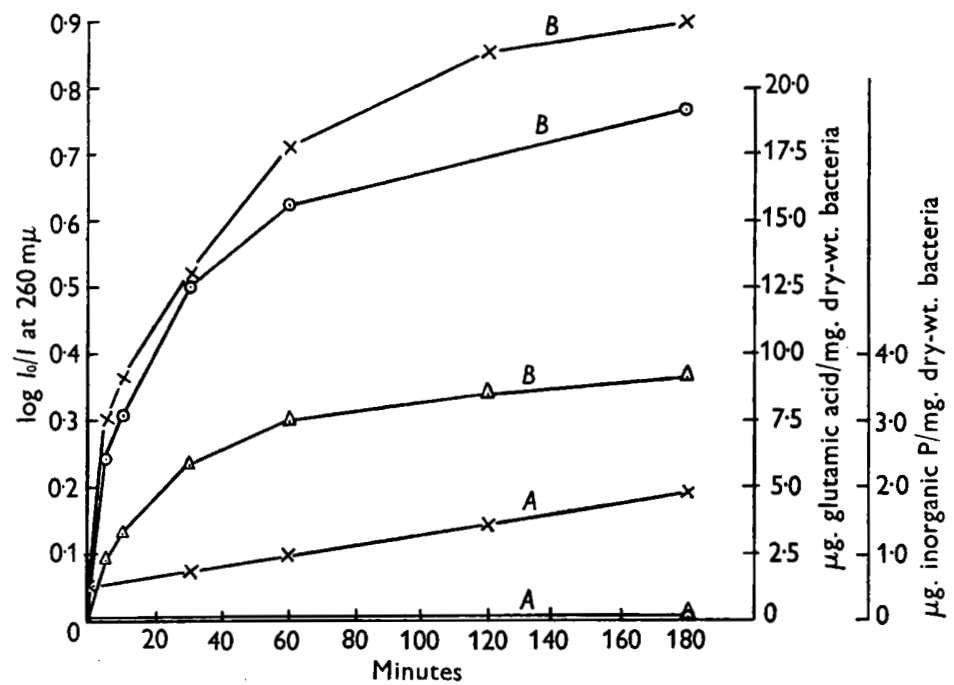

Fig. 3. The course of release of cellular constituents from Staph. aureus (1.5 mg. dry-wt. cells/ml.) suspensions at $20^{\circ}$, the amount of constituents appearing in the supernatant being plotted against time. $\times-\subset, 260 \mathrm{~m} \mu$-absorbing material; $\odot-\bigcirc$, glutamic acid; $\triangle \longrightarrow \triangle$, inorganic $P$; $A$, cells suspended in water; $B$, cells suspended in a solution containing $90 \mu \mathrm{g}$. CTAB $/ \mathrm{ml}$.

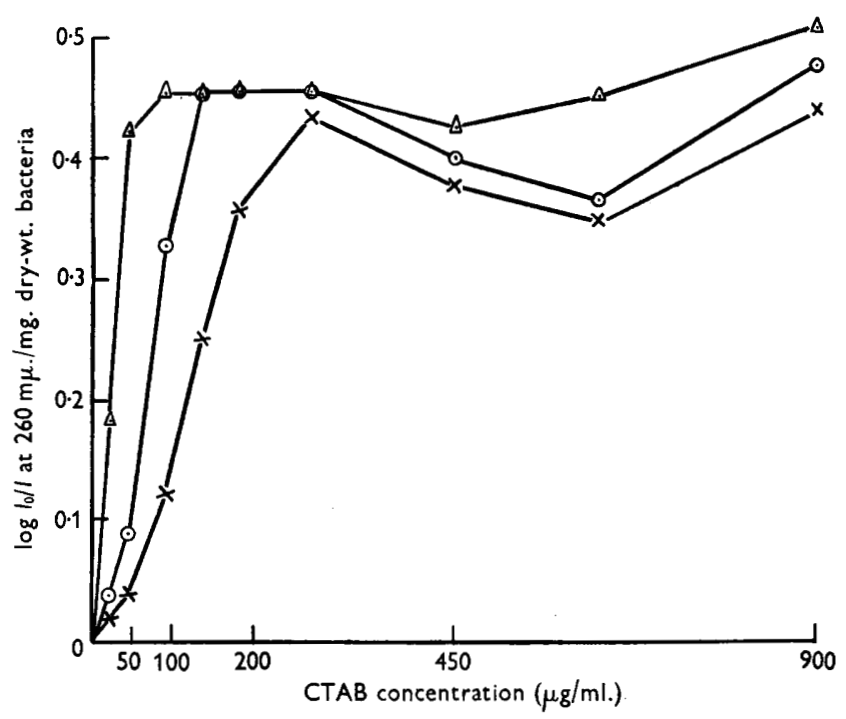

Fig. 4. Effect of CTAB concentration on the release of $260 \mathrm{~m} \mu$.-absorbing material from Staph. aureus at $20^{\circ}$. The amount of $260 \mathrm{~m} \mu$.-absorbing material released into the suspending fluid was estimated for: $\times \longrightarrow \times, 5$ min. exposure; $\odot \longrightarrow-\odot, 30$ min. exposure; $\triangle-\triangle, 180$ min. exposure. 
Table 6. Relationship between percentage cells killed, amount of CTAB and release of $260 \mathrm{~m} \mu$. -absorbing material at $20^{\circ}$

\begin{tabular}{|c|c|c|c|c|c|c|}
\hline \multirow[b]{2}{*}{ Organism } & \multirow{2}{*}{$\begin{array}{c}\text { Dry-wt. } \\
\text { bacteria } \\
\text { (mg./ml.) }\end{array}$} & & \multicolumn{2}{|c|}{$22.5 \mu \mathrm{g} . \mathrm{CTAB} / \mathrm{ml}$} & \multicolumn{2}{|c|}{$45 \mu \mathrm{g}$. CTAB/ml. } \\
\hline & & & $\begin{array}{l}5 \text { min. } \\
\text { exposure }\end{array}$ & $\begin{array}{l}30 \text { min. } \\
\text { exposure }\end{array}$ & $\begin{array}{l}5 \mathrm{~min} . \\
\text { exposure }\end{array}$ & $\begin{array}{l}30 \text { min. } \\
\text { exposure }\end{array}$ \\
\hline Staph. aureus & $1 \cdot 8$ & $\begin{array}{l}\text { Killed }(\%) \\
260 \mathrm{~m} \mu . \text { material } \\
\text { released } \\
\left(\log I_{0} / I\right)\end{array}$ & $\begin{array}{l}24 \\
0 \cdot 036\end{array}$ & $\begin{array}{l}35 \\
0.061\end{array}$ & $\begin{array}{l}\mathbf{5 0} \\
\mathbf{0 . 0 7 1} \\
.\end{array}$ & $\begin{array}{l}62 \\
0 \cdot 116\end{array}$ \\
\hline Strep. faecalis & $1 \cdot 5$ & $\begin{array}{l}\text { Killed (\%) } \\
260 \mathrm{~m} \mu . \text { material } \\
\text { released } \\
\left(\log I_{0} / I\right)\end{array}$ & $\begin{array}{l}\mathbf{4 3} \\
0 \cdot 255\end{array}$ & $\begin{array}{l}\mathbf{5 5} \\
0 \cdot 315\end{array}$ & $\begin{array}{l}85 \\
0.508\end{array}$ & $\begin{array}{l}97 \\
0.571\end{array}$ \\
\hline Esch. coli & $1 \cdot 4$ & $\begin{array}{l}\text { Killed (\%) } \\
260 \text { m } \mu . \text { material } \\
\text { released } \\
\left(\log I_{0} / I\right)\end{array}$ & $\begin{array}{l}16 \\
0.049\end{array}$ & $\begin{array}{l}28 \\
0 \cdot 069\end{array}$ & $\begin{array}{l}31 \\
0.094\end{array}$ & $\begin{array}{l}57 \\
0 \cdot 137\end{array}$ \\
\hline Salm. pullorum & $1 \cdot 5$ & $\begin{array}{l}\text { Killed (\%) } \\
260 \text { m } \mu . \text { material } \\
\text { released } \\
\left(\log I_{0} / I\right)\end{array}$ & $\begin{array}{l}26 \\
0 \cdot 156\end{array}$ & $\begin{array}{l}31 \\
0 \cdot 175\end{array}$ & $\begin{array}{l}54 \\
0.314\end{array}$ & $\begin{array}{l}62 \\
0 \cdot 347\end{array}$ \\
\hline
\end{tabular}

Autolysis initiated by $C T A B$ treatment

When the appearance of cellular constituents in the suspending fluid was followed over an extended period, autolytic breakdown of the cells did contribute to the amount of materials found in the supernatants, as suggested by the data of Hotchkiss (1944, 1946). The appearance of $260 \mathrm{~m} \mu$.-absorbing material and pentose in the suspending fluid from Staph. aureus treated with $90 \mu \mathrm{g}$. $\mathrm{CTAB} / \mathrm{ml}$. at $30^{\circ}$ was followed together with the Gram-stain reaction of the cells and changes in the dry weight of centrifuge-deposited untreated and CTAB-treated bacteria (i.e. cells freed from the supernatant fluid). These measurements are recorded in Table 7.

The results show an initial leakage process which is completed in 3-4 hr. This is then followed by a slower release of constituents, accompanied by a gradual change in staining from Gram-positive to Gram-negative and a progressive decrease in dry-cell mass. The results with this organism therefore appear to differ from those of Hotchkiss (1946) in that autolytic breakdown of the cells does not appear to contribute significantly to the amounts of cellular constituents released within the first few hours of exposure of the cells to CTAB.

\section{DISCUSSION}

Bacterial cells have a high affinity for CTAB molecules. For the six organisms studied, the amount of CTAB adsorbed per cell, at saturation levels, was found to be more than the amount corresponding to a closely packed monolayer of the detergent. CTAB molecules occupy an area of c. $45 \mathrm{A.}^{2}$ (Friend \& Schulman, private communication). The amount of CTAB taken up at saturation of Staph. aureus would, therefore, occupy an area c. 15 times the cell surface area (assuming a sphere of $1 \mu$. in diameter). The corresponding ratio for $B$. pumilus is 
Table 7. Release of cell constituents, changes in dry weight and Gram-stain of untreated and CTAB-treated suspensions of Staph. aureus held at $30^{\circ}$

A, untreated cells. B, cells treated with $90 \mu \mathrm{g}$. CTAB $/ \mathrm{ml}$.

\begin{tabular}{|c|c|c|c|c|c|c|c|c|}
\hline \multirow[b]{2}{*}{ Time } & \multicolumn{2}{|c|}{$\begin{array}{c}260 \mathrm{~m} \mu_{\text {.-material }} \\
\log \left[I_{0} / I\right]\end{array}$} & \multicolumn{2}{|c|}{$\begin{array}{l}\text { Pentose } \\
(\mu \mathrm{g} . / \mathrm{ml} .)\end{array}$} & \multicolumn{2}{|c|}{$\begin{array}{c}\text { Dry wt. } \\
\text { (mg./10 ml. sample) }\end{array}$} & \multicolumn{2}{|c|}{$\begin{array}{c}\text { Gram stain } \\
\text { (approx. } \% \text { Gram- } \\
\text { positive) }\end{array}$} \\
\hline & $\mathbf{A}$ & $\mathbf{B}$ & $\mathbf{A}$ & B & $\mathbf{A}$ & B & $\mathbf{A}$ & B \\
\hline $0 \mathrm{~min}$. & $0 \cdot 12$ & $0 \cdot 12$ & 0 & o & $19 \cdot 7$ & $19 \cdot 7$ & 100 & 100 \\
\hline 5 min. & - & 0.38 & - & - & - & $10 \cdot 4$ & 100 & 100 \\
\hline $10 \mathrm{~min}$. & - & 0.45 & - & $3 \cdot 2$ & - & $19 \cdot 5$ & 100 & 100 \\
\hline 20 min. & - & 0.64 & - & 4.2 & - & 18.5 & 100 & 100 \\
\hline $40 \mathrm{~min}$. & - & 0.96 & - & $6 \cdot 3$ & - & $18 \cdot 3$ & 100 & 100 \\
\hline $60 \mathrm{~min}$. & $0 \cdot 26$ & $1 \cdot 12$ & 0.9 & $8 \cdot 1$ & $19 \cdot 6$ & $17 \cdot 5$ & 100 & 100 \\
\hline $120 \mathrm{~min}$. & 0.40 & $1 \cdot 31$ & 1.0 & $9 \cdot 0$ & 19.2 & $16 \cdot 6$ & 100 & 100 \\
\hline $180 \mathrm{~min}$. & 0.56 & $1 \cdot 42$ & - & $9 \cdot 8$ & - & 16.8 & 100 & 100 \\
\hline $4 \mathrm{hr}$. & $0 \cdot 70$ & 1.44 & - & $9 \cdot 7$ & $18 \cdot 9$ & $16 \cdot 3$ & 100 & 100 \\
\hline $6 \mathrm{hr}$. & 0.94 & 1.54 & - & - & - & 15.9 & 100 & 90 \\
\hline $8 \mathrm{hr}$. & - & $1 \cdot 64$ & - & $12 \cdot 3$ & - & $15 \cdot 6$ & 100 & 75 \\
\hline $10 \mathrm{hr}$. & $1 \cdot 30$ & 1.76 & $2 \cdot 0$ & - & $18 \cdot 4$ & $15 \cdot 3$ & 100 & 50 \\
\hline $12 \mathrm{hr}$. & - & $1 \cdot 84$ & - & - & $18 \cdot 6$ & $15 \cdot 1$ & 100 & 25 \\
\hline $13 \mathrm{hr}$. & $1 \cdot 57$ & 1.92 & $2 \cdot 2$ & $15 \cdot 0$ & - & $15 \cdot 1$ & 100 & 10 \\
\hline $22 \mathrm{hr}$. & - & - & - & $21 \cdot 0$ & $18 \cdot 4$ & 14.8 & 100 & 0 \\
\hline $28 \mathrm{hr}$. & - & $2 \cdot 40$ & - & 24.3 & & $18 \cdot 3$ & 100 & 0 \\
\hline
\end{tabular}

c. 18 times the cell-surface area, assuming cell dimensions of $0 \cdot 8 \mu$. width, $3 \mu$. length. This suggests that CTAB is adsorbed at sites additional to those available at the cell surface, if it be all adsorbed as a monolayer. Alexander \& McMullen (1949) and McQuillen (1950) also suggested the possibility of CTAB adsorption at sites within the bacterial cytoplasm. Valko \& Dibblee (1944) reported that adsorption of dimethyldodecylbenzylammonium chloride by Esch. coli corresponded to an equivalent weight of the bacterium of $c .600$, an equivalent weight about the same as that of many animal proteins. It would seem, therefore, that both surface and internal components of the bacterial cell are capable of titrating with cationic detergents. McQuillen (1950) suggested the possibility of some detergent being held as concentric shells around the bacterial cell, but his electrophoresis data afforded no confirmation of this. However, the agglutination of bacterial suspensions at CTAB-saturation levels indicates that the surface of the cells has become hydrophobic, a phenomenon analogous to the agglutination of red blood cells with tannic acid, observed by Schulman \& Rideal (1937).

As Anson (1939) pointed out, any study of killing and lysis of bacteria by detergents should include a series of concentrations in order to determine the chain of reactions that occur in the organism. From the work reported here, it is possible to appreciate something of the course of events when bacteria are exposed to the cationic detergent CTAB. On exposure of various species to bactericidal amounts of CTAB below that required for $99.99 \%$ killing, the leakage of $260 \mathrm{~m} \mu$.-absorbing material in $5 \mathrm{~min}$. is proportional to the percentage of cells killed. These observations are in agreement with the quantitative relationship between the proportion of cells killed by different amounts of 
tyrocidin and release of amino-acids reported by Gale \& Taylor (1947). When cell suspensions are treated with sufficient CTAB (c. $90 \mu \mathrm{g}$. CTAB/1.5 mg. dryweight cells) to kill $99.99 \%$ of the cells within 5 min., the rapidity with which cellular constituents appear in the suspending fluid varies from one organism to another. Where the release of cellular constituents was found to be relatively slow (e.g. 3-4 hr. with Staph. aureus) temperature affected the rate of leakage of materials into the suspending fluid. Cellular constituents were also more rapidly released when suspensions were treated with amounts of CTAB above those exhibiting maximum killing.

The results reported here support the view that there is a primary process of cell-solute release on treatment of bacteria with CTAB. Autolytic breakdown of the cells does not appear to make a significant contribution to the materials found in the suspending fluid during this initial leakage. This conclusion is supported by the following experimental observations: (1) the parallel relationship between the release of free amino-acid, inorganic $\mathbf{P}$, purines and pyrimidines, etc.; (2) the amounts of cellular constituents released from bacteria exposed to $90 \mu \mathrm{g}$. CTAB $/ \mathrm{ml}$. for $180 \mathrm{~min}$. at $20^{\circ}$ were comparable to the amounts released from 'boiled' cells; (3) a change in the Gram-staining of Staph. aureus was not apparent until several hours after the initial leakage of cell solutes (Table 7). However, a study of cell constituents released when suspensions were treated with $90 \mu \mathrm{g}$. CTAB $/ \mathrm{ml}$. and held for periods of more than 3-4 hr. or treated with CTAB concentrations near and above the level required for cell saturation, suggested that processes such as autolytic breakdown, adsorption of released materials on to CTAB-saturated cells and solubilization of cell materials in detergent micelles were involved. Autolysis of bacteria associated with treatment of cells in low and high concentrations of surface-active agents has been well established in previous studies. This phenomenon was reviewed by Dubos (1945), and Hotchkiss (1946) has contributed further information. The possibility of physical solubilization of cellular materials in bacteria + detergent studies has been suggested by the work of Stacey (1949).

That treatment of bacteria and yeasts with detergents results in cellular disorganization is further supported by cytological evidence of cytoplasmic shrinkage, cell rupture, etc. (Dyar, 1947; Mitchell \& Crowe, 1947; Meisel \& Umanskaya, 1949; Salton et al. 1951).

Knox et al. (1949) believe that specific inhibition of a detergent-sensitive enzyme, such as the lactic acid oxidase of Esch. coli, can account for the metabolic inhibition, cell death and increased permeability observed in bacteria treated with cationic detergents. It does not seem to be necessary to invoke the inhibition of a detergent-sensitive enzyme as being the primary cause of cell death. Indeed, if there were a chain of reactions initiated by a primary metabolic inhibition, a greater time lag before the observation of secondary effects such as the release of cellular constituents might well be expected. However, it appears that leakage of cell solutes, inhibition of sensitive enzymes and cytological damage can all be observed simultaneously with cell death. The interaction between detergent molecules and cell components (e.g. 
proteins, enzymes, lipo-proteins etc.) as such, could account for cell death, leakage of solutes, etc. Studies of the penetration of protein and lipo-protein mono-layers by surface-active compounds, discussed by Schulman (1951), appear to have some relevance to the action of these agents on the permeability barrier of bacteria. It would seem that there is little evidence which disagrees with the original hypothesis of cell membrane disorganization proposed by Baker et al. (1941). However, it is yet too early to speculate on the primary site or sites of detergent action. A clearer picture will undoubtedly emerge when more is known of the chemical nature of the surface components and outer envelope of the bacterial cell.

This work was performed during the tenure of a Studentship, for which I am indebted to the Commonwealth Scientific and Industrial Research Organization of Australia. I also wish to express my sincere thanks to Prof. A. E. Alexander, Dr J. H. Schulman and Dr E. F. Gale for their interest, encouragement and helpful criticism throughout the course of the investigations.

\section{REFERENCES}

Alexander, A. E. \& McMullen, A. I. (1949). Surface Chemistry, p. 309. London: Butterworth's Scientific Publications.

Anson, M. L. (1939). The denaturation of proteins by synthetic detergents and bile salts. J. gen. Physiol. 23, 239.

Baker, Z., Harrison, R. W. \& Miller, B. F. (1941). Inhibition by phospholipids of the action of synthetic detergents on bacteria. J. exp. Med. 74, 621 .

Dubos, R. J. (1945). The Bacterial Cell. Harvard University Press.

Dyar, M. T. (1947). A cell wall stain employing a cationic surface active agent as a mordant. J. Bact. 53, 498.

Fiske, C. H. \& Subbarow, Y. (1925). The colorimetric determination of phosphorus. J. biol. Chem. 66, 375.

Gale, E. F. (1945). Studies on bacterial amino-acid decarboxylases. 5. The use of specific decarboxylase preparations in the estimation of amino-acids and in protein analysis. Biochem. J. 39, 46.

Gale, E. F. \& TAYLor, E. S. (1947). The assimilation of amino-acids by bacteria. 2 . The action of tyrocidin and some detergent substances in releasing amino-acids from the internal environment of Streptococcus faecalis. J. gen. Microbiol. 1, 77.

Hотснкiss, R. D. (1944). Advances in Enzymology, 4, 153.

Hотснкiss, R. D. (1946). The nature of the bactericidal action of surface active agents. Ann. N.Y. Acad. Sci. 46, 479.

HотснкISs, R. D. (1948). The quantitative separation of purines, pyrimidines, and nucleosides by paper chromatography. J. biol. Chem. 175, 315.

Knox, W. E., Auerbach, V. H., Zarudnaya, K. \& Spirtes, M. (1949). The action of cationic detergents on bacteria and bacterial enzymes. J. Bact. 58, 443.

Kunn, R. \& BieLig, H. J. (1940). Ueber Invertseifen. I. Die Einwirkung von Invertseifen auf Eiweiss-Stoffe. Ber. dtsch. chem. Ges. 73, 1080.

MCQUILLEN, K. (1950). The bacterial surface. 1. Effect of cetyltrimethylammonium bromide on the electrophoretic mobility of certain Gram-positive bacteria. Biochim. biophys. Acta, 5, 463.

Markham, R. \& Smith, J. D. (1949). Chromatographic studies of nucleic acids. 1. A technique for the identification and estimation of purine and pyrimidine bases, nucleosides and related substances. Biochem. J. 45, 294.

Meisel, M. N. \& UmanskaYa, V. P. (1949). On the action of quaternary ammonium compounds on the bacterial cell. Mikrobiol. (U.S.S.R.) 18, 11. 
Mejbaum, W. (1939). Über die Bestimmung kleiner Pentosemengen, insbesondere in Derivaten der Adenylsaure. Z. physiol. Chem. 258, 117.

Mrtchell, P. D. \& Crowe, G. R. (1947). A note on electron micrographs of normal and tyrocidin-lysed Streptococci. J. gen. Microbiol. 1, 85.

Salton, M. R. J. (1950). The bactericidal properties of certain cationic detergents. Aust. J. sci. Res. 3, 45.

Salton, M. R. J. \& Alexander, A. E. (1949). Estimation of soaps and ionized detergents. Research, 2, 247.

Salton, M. R. J. \& Alexander, A. E. (1950). The release of cellular constituents from Staphylococcus aureus treated with cetyltrimethylammonium bromide. J. gen. Microbiol. 4, ii.

Salton, M. R. J., Horne, R. W. \& Cosslett, V. E. (1951). Electron microscopy of bacteria treated with cetyltrimethylammonium bromide. J. gen. Microbiol. $5,405$.

Schulman, J. H. (1951). Cytology and Cell Physiology, 2nd ed. p. 119. Oxford: Clarendon Press. (In the Press.)

Schulman, J. H. \& Rideal, E. K. (1937). Molecular interaction in monolayers. II. The action of haemolytic and agglutinating agents on lipo-protein monolayers. Proc. Roy. Soc. B, 122, 46.

Stacey, M. (1949). In The Nature of the Bacterial Surface, ed. A. A. Miles \& N. W. Pirie, p. 29. Oxford: Blackwell Scientific Publications.

TAYLOR, E. S. (1947). The assimilation of amino-acids by bacteria. 3. Concentration of free amino-acids in the internal environment of various bacteria and yéasts. J. gen. Microbiol. $1,86$.

Umbreit, W. W., Burris, R. H. \& Stauffer, J. F. (1945). Manometric Techniques and Related Methods for the Study of Tissue Metabolism. Minneapolis: Burgess Publishing Co.

VAlko, E. I. (1946). Surface active agents in biology and medicine. Ann. N.Y. Acad. Sci. 46, 451 .

Valko, E. I. \& DibBlee, D. (1944). See Valko (1946). 